\title{
High-cyclic failure analysis of welded cast iron plates
}

\author{
R. Stonkus*, M. Leonavičius**, G. Petraitis***, S. Stupak**** \\ *Vilnius Gediminas Technical University, Sauletekioal.11,10223Vilnius, Lithuania, E-mail: rs@fm.vgtu.lt \\ **Vilnius Gediminas Technical University, Saulètekio al.11,10223 Vilnius, Lithuania, E-mail: minleo@fm.vgtu.lt \\ ***Vilnius Gediminas Technical University, Sauletekio al. 11,10223 Vilnius, Lithuania, E-mail: gedp@vgtu.lt \\ ****Vilnius Gediminas Technical University, Sauletekio al.11,10223Vilnius, Lithuania, E-mail: stupakas@vgtu.lt \\ crossref http://dx.doi.org/10.5755/j01.mech.17.2.325
}

\section{Introduction}

None of any known techniques of welding guaranties a welded joint without a defect. The regulated sizes of defects are conditional. If a defect is found during a control or service exceeds the normal size, often a doubt arises whether to reject it or after performing some calculations to make clear that the crack appeared during operation does not cause the structural element critical state - failure [1-3].

The type of welded joint, selected at the design stage causes the development of stress concentrators, which can be supplemented by some technological defects. Structural and technological concentrators during operation are agents stimulating beginning of the failure [3-13].

The weld material of the joint should be of a uniform or increased strength than the base metal. However, during operation under the influence of cyclic stresses, the concept of uniform or larger strength condition changes and origins of cracks may be developed at the surface irregularities or of welding defects in weld material or in the heat affected zone.

In mining industry, some large elements are cast of cast iron and welded together then. The composition of base metal and weld material are different [8].

\section{Testing procedures}

Two cast iron plates are prepared in such a way that they should make a butt joint with double $-\mathrm{V}$ shape weld. The experimental part in the vicinity of the weld material is treated by an abrasive disc in the same way, as in a real structure. When doing in this way, some scratching remains, namely, concentrations. In joining places and supporting point fields, these places are grinded. The sam- ple is pushed lengthwise up to $5 \mathrm{~mm}$ in order to diminish the contact influence between the plate and supporting rollers, as shown in Fig. 1.

The chemical composition of the base metal: C$3.64 \%$, Si- $1.90 \%$, Mn- $0.35 \%$, Mo- $0.03 \%$, Cu- $0.210 \%$, Cr$0.071 \%$ and the weld: C- $0.08 \%$, Si- $0.46 \%, \mathrm{Mn}-0.65 \%$, Mo- $0.03 \%$, Cu- $0.025 \%$, Cr- $0.011 \%$.

The static mechanical properties were determined from cylindrical tensile specimens $\left(d_{0}=8.00 \mathrm{~mm}\right.$; $L_{0}=30.0 \mathrm{~mm}$ ) from base metal (cast iron): conditional yield stress $R_{p 0.2}=490-500 \mathrm{MPa}$, ultimate strength $R_{m}=817 \mathrm{MPa}$, elasticity module $E=175 \mathrm{GPa}$, elongation $A=2.13 \%$, reduction in area $Z=4.94 \%$ and the weld: upper yield stress $R_{e H}=408-469 \mathrm{MPa}$, lower yield stress $R_{e L}=392-440 \mathrm{MPa}, \quad R_{m}=529 \mathrm{MPa}, \quad E=209 \mathrm{GPa}$, $A=25.2 \%, Z==59.4 \%$.

The hardness of weld metal $(147-179 \mathrm{HB})$ is less about 1.5 times than it is of base metal $(225-261 \mathrm{HB})$ and less about 1.8 times of heat affected zone (268-309 HB).

An experimental investigation of the resistance to the high-cyclic loading is performed by the loading scheme, as shown in Fig. 1. The history of the program loading is shown in Fig. 2. It is interesting that under the stress $\sigma_{\text {max }}=42.8 \mathrm{MPa}, \sigma_{\min }=-26.2 \mathrm{MPa}$ (cycle asymmetry $r=-0.62$ ) the specimen passed 100 million cycles in $150 \mathrm{MPa}$ stress change interval, but the initial cracking was not fixed. This loading history corresponds to the real loading of structure elements. By a periodical stopping the machine, the nondestructive inspection of the investigated part was performed by luminescent, optical and ultrasonic methods. Some crack origins, i.e. the development of the defectoscopy picture, was detected at $\Delta \sigma=120 \mathrm{MPa}$. The development of crack origin was fixed after 130 million cycles in $150 \mathrm{MPa}$ stress change interval.

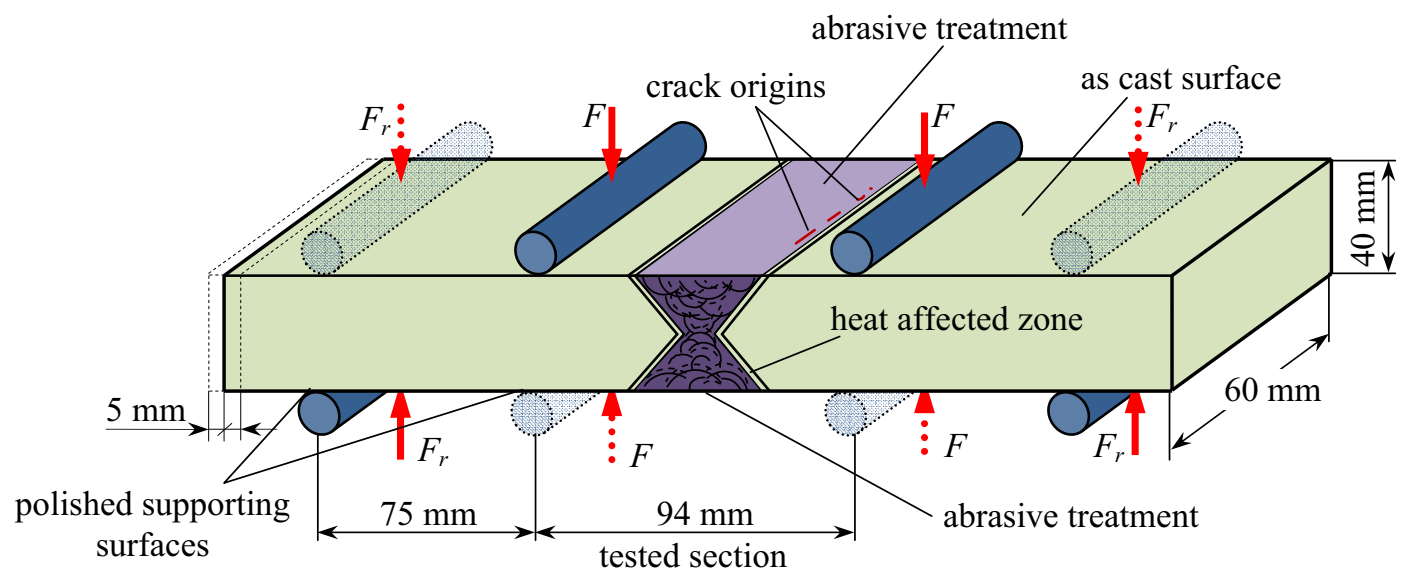

Fig. 1 The loading scheme of the specimen 


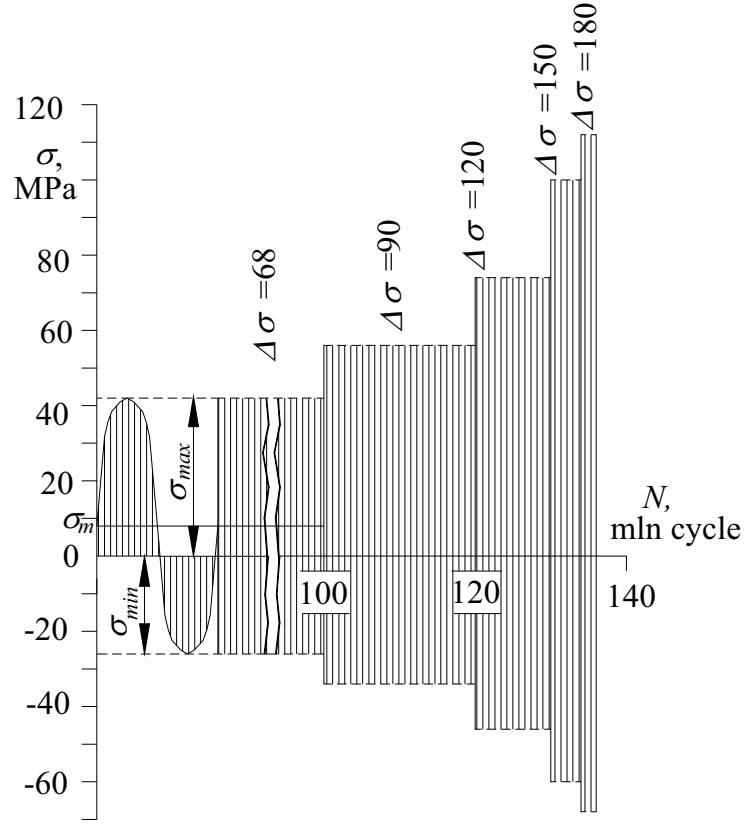

Fig. 2 Loading history diagram
Fig. 3 presents the microstructure of welded joint (with no etching) in heat affected zone when crossing from weld metal to the main one. Spheroid graphite can be distinguished there. When approaching the weld metal, it can be seen that the graphite shape and quantity change: beside a spheroid graphite there appears the field of small graphite and the remained graphite acquires the shape of flakes. Fig. 4 shows the structure of weld metal (carbon steel) and the base metal (cast iron) after etching. Here we can also see different derivatives in the heat affected zone, the graphite of spherical and flake-shapes in a ferrite-pearlite matrix and even graphite chains with a small dross layer. The irregularity of the graphite inclusions and the change in their shape also change the mechanical properties, and all this influence the resistance to cyclic loading. The metallic base of the basic metal consists of ferritic-pearlitic structure. By the chemical composition, mechanical properties and the structure it is possible to establish, that the plates are made of a strong cast iron. Such an iron is quite plastic, tensile, resistant to impact loading and easy welded after selecting a proper technology and a material for electrodes. Testing of such a connection for cyclic loading according to the programme coordinated with real structural element operational loading, when the number of cycles exceeds $10^{8}$, is necessary for ensuring the longevity for the exploited and being designed structures [14-19].

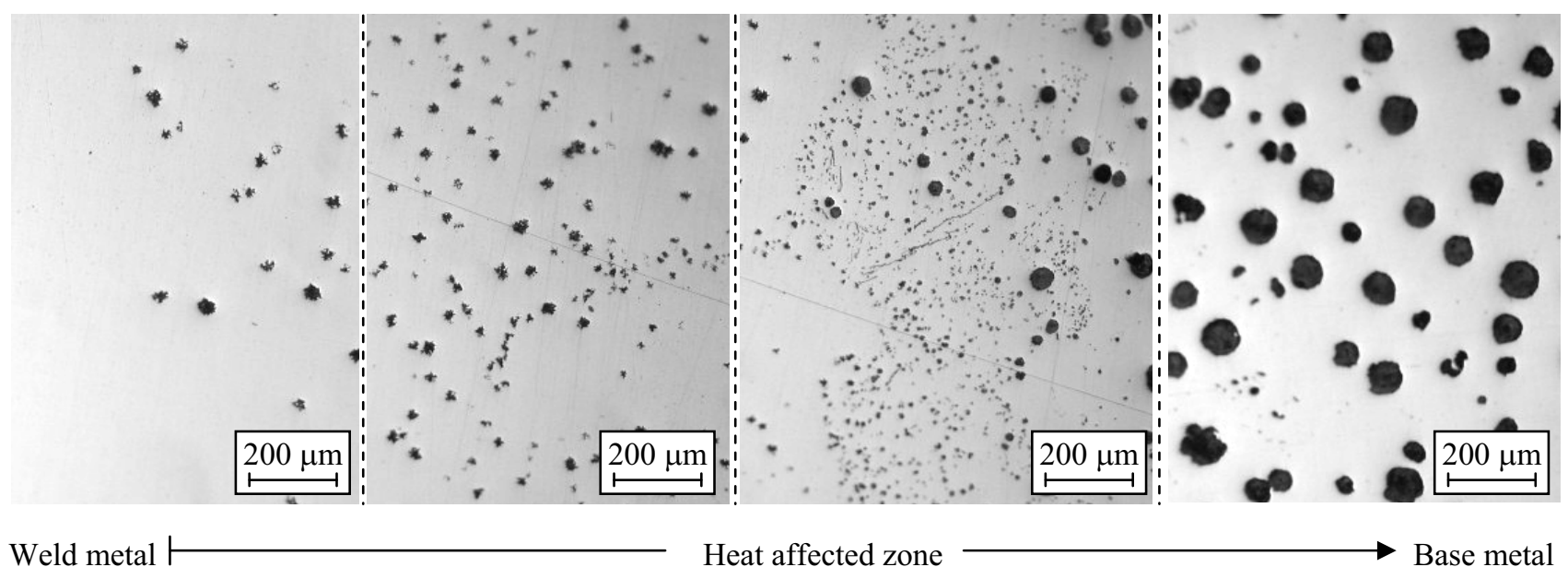

Fig. 3 The microstructure (without etching) in the heat affected zone from weld metal to the main one

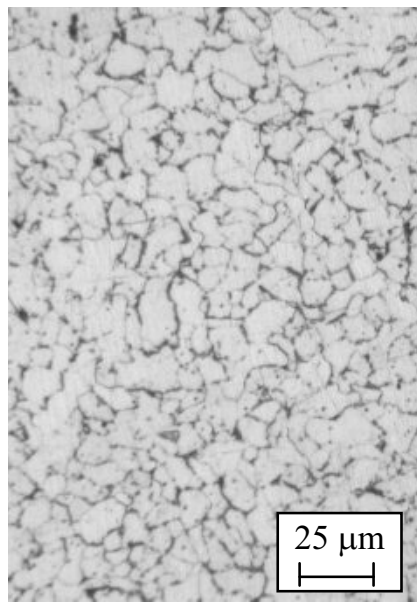

a

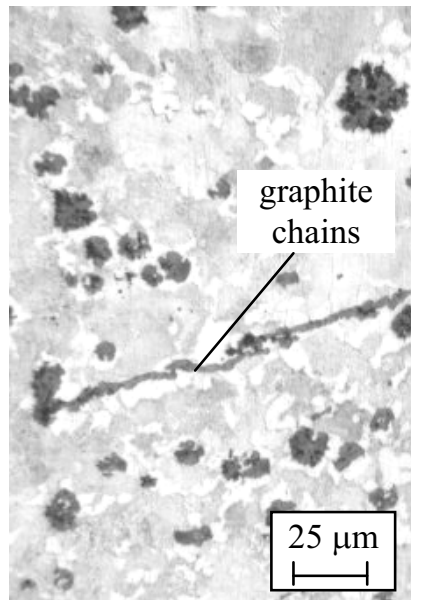

$\mathrm{b}$

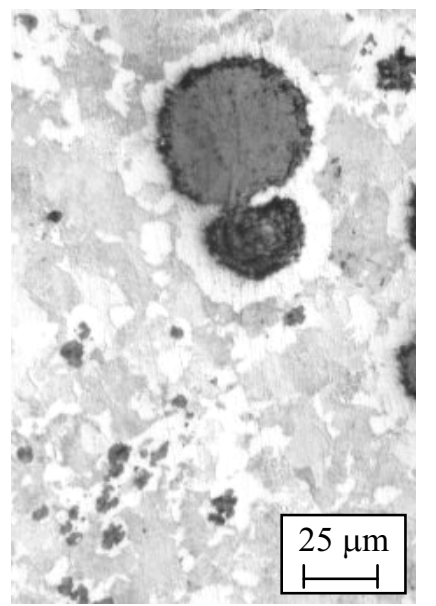

$\mathrm{c}$

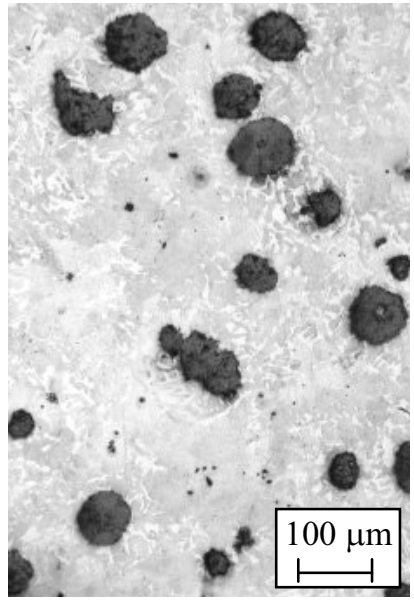

d

Fig. 4 The microstructure of specimen (etched): a - weld metal (steel); b, c-heat affected zone; $d$ - base metal (cast iron) 
From the point of view of the fracture mechanics the fatigue diagram is important - the dependence of crack growth rate on stress intensity factor $K$, allowing to estimate the material cyclic strength from the beginning of crack formation up to complete failure. The parameters of the curve (kinetic fatigue diagram) define the resistance of the material to a cyclic loading. According to the experimental data obtained (crack depth - number of cycles) the kinetic diagrams are designed applying 3 different formulas for $K$ calculation:

$$
\begin{aligned}
& \text { 1) Anderson [13] } \\
& K_{\mathrm{I}}=\frac{M}{B \sqrt[3]{W}} f\left(\frac{a}{W}\right)
\end{aligned}
$$

where $M$ is bending moment, $B$ is specimen width, $W$ is thickness, $a$ is crack size, $f(a / W)$ is dimensionless geometry function

$$
\begin{aligned}
& f\left(\frac{a}{W}\right)=\frac{6 \sqrt{2 \tan \left(\frac{\pi a}{2 W}\right)}}{\cos \left(\frac{\pi a}{2 W}\right)} \times \\
& \times\left[0.923+0.199\left\{1-\sin \left(\frac{\pi a}{2 W}\right)\right\}^{4}\right]
\end{aligned}
$$

2) Tada, Paris, Irwin [14]:

$$
K_{\mathrm{I}}=\frac{6 M}{t W^{2}} \sqrt{\pi a} f\left(\frac{a}{W}\right)
$$

where $M$ is bending moment, $t$ is width, $W$ is thickness, $a$ is crack size, $f(a / W)$ is geometry function

$$
\begin{aligned}
& f\left(\frac{a}{W}\right)=\left(\frac{2 W}{\pi a} \tan \frac{\pi a}{2 W}\right)^{1 / 2}\left(\cos \frac{\pi a}{2 W}\right)^{-1} \times \\
& \left(0.923+0.199\left(1-\sin \frac{\pi a}{2 W}\right)^{3}\right)
\end{aligned}
$$

3) ASTME [15]

$$
K_{\mathrm{I}}=\sigma \sqrt{\pi a} f(\alpha)
$$

where $\sigma$ is maximal stresses, $a$ is crack size, $\alpha=a / W$, $f(\alpha)$ is correction function according to a formula

$$
f(\alpha)=1.122-1.40 \alpha+7.33 \alpha^{2}-13.08 \alpha^{3}+14.0 \alpha^{4}
$$

According to some calculations, kinetic diagrams are made (crack growth rate - stress intensity factor) in Fig. 5. It is known that for determination of fracture toughness $K_{C}$, the crack can be grown before it under low-cycle or high-cycle loading. By making a variety of materials kinetic fatigue diagrams, the specimens with cracks can be used for the determination of factors $\Delta K_{t h}$ and $K_{C}$. In our case, the threshold stress intensity factors $\Delta K_{t h}$ and $K_{C}$ chosen according to the kinetic fatigue diagram can be used to calculate the structural elements.

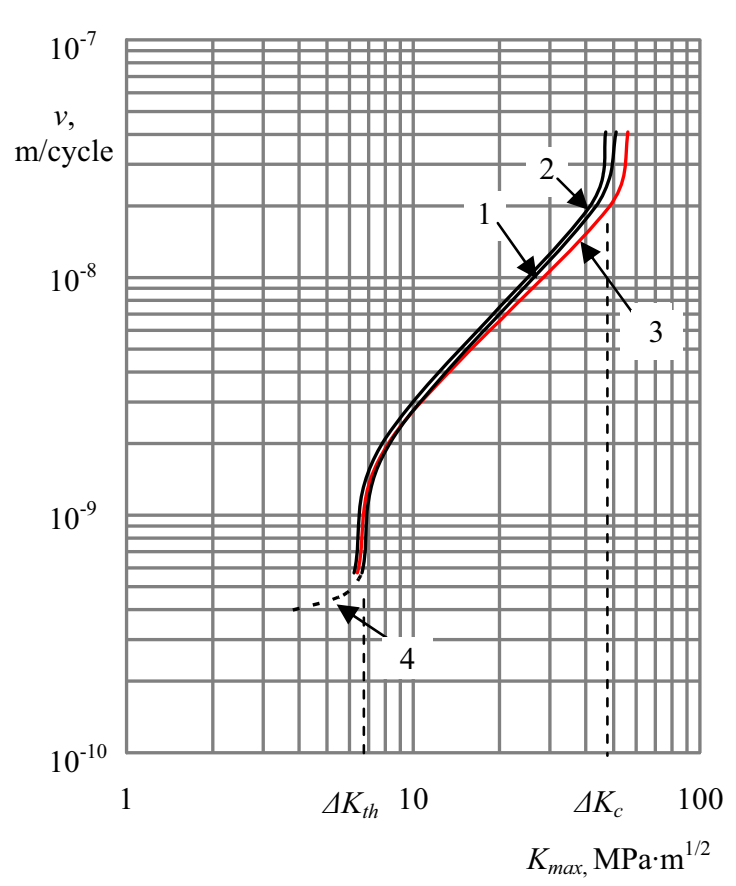

Fig. 5 Kinetic diagram of fatigue: 1 - Anderson, 2 - Tada, Paris, Irvine, 3 - ASTME, 4 - short crack

In the figure we can see that all the formula applied give similar results. Also characteristic stages of fracture are seen at it. For on its structure a large influence has been produced on the maximal meaning of loading value. An important diagram characteristics is the threshold stress intensity factor range, because it shows a crack nongrowing conditions in the specimen. Cracks developing below the cracking threshold are called short and more or less correspond to the spreading through a coarse-grained structure. In Fig. 5 a short cracking field is approximate; it is calculated by the Anderson's formula (1). For developing short cracks the microstructure has of the greatest importance. The middle part of the diagram is the macroscopic crack development; and it takes place, when the crack growth rate is from $10^{-9} \mathrm{~m} /$ cycle to $2 \cdot 10^{-8} \mathrm{~m} /$ cycle. It is the stable crack development stage, limited from the right side by fracture toughness $K_{C}$, which determines the end of crack developing stadium and the further sudden failure.

The fracture analysis enriches understanding of the conditions of crack formation, growing and total failure. The crack has appeared in the surface layer of weld metal (Fig. 6).

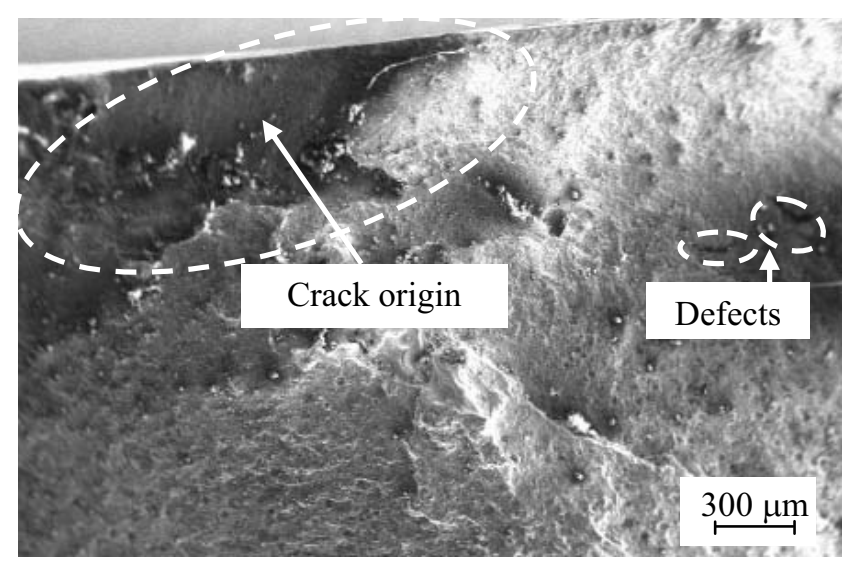

Fig. 6 The place of crack origin 
It has been found that the crack is originated at the defect ( $1-2 \mathrm{~mm}$ depth) in a transitional zone from a weld material towards the base metal (transitional zone is made clearer in Fig. 7). During a defectoscope control the crack has been observed, when it has appeared on the surface.

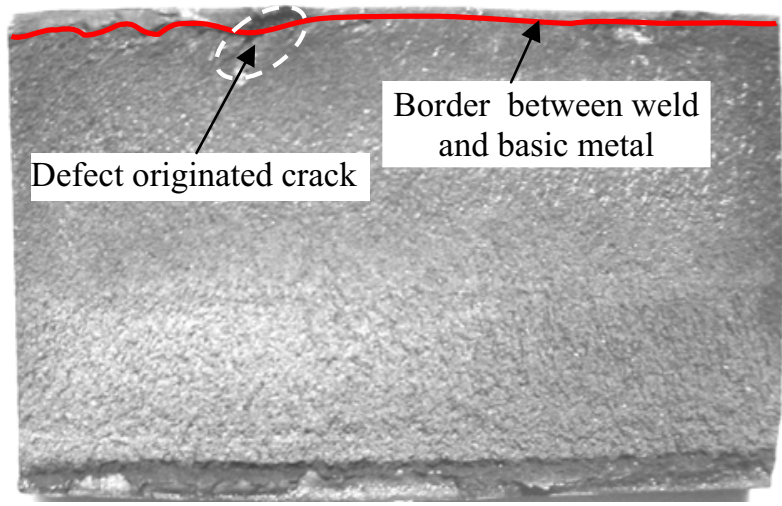

Fig. 7 Fracture of the specimen

Further the crack is growing through the weld metal and moves to the base metal (Fig. 8).

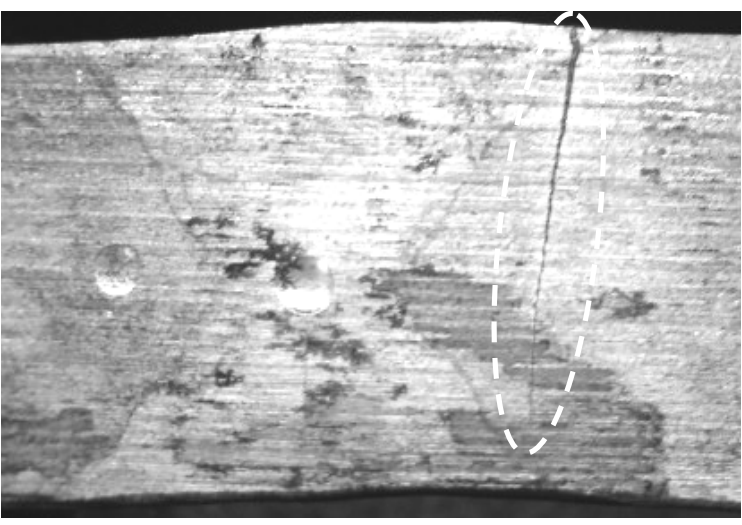

Fig. 8 Crack development in depth

When intruding into the main metal (cast iron) in the transitional zone (the heat affect zone) the crack meets inside defects: pores, nonmetallic insertions (Fig. 9), which increase the crack growth rate.

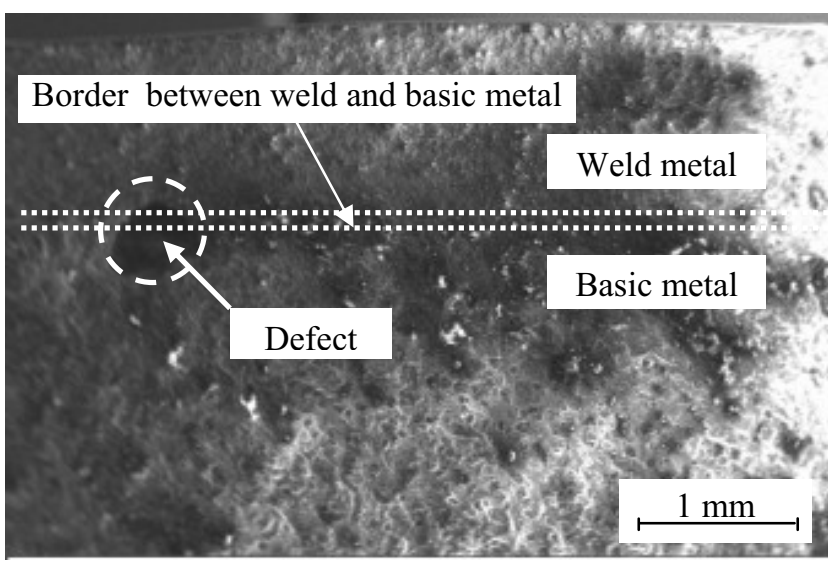

Fig. 9 The increased area of sample break

In Fig. 10 a large accumulation of defects is seen, formed during welding.
Surface of the specimen

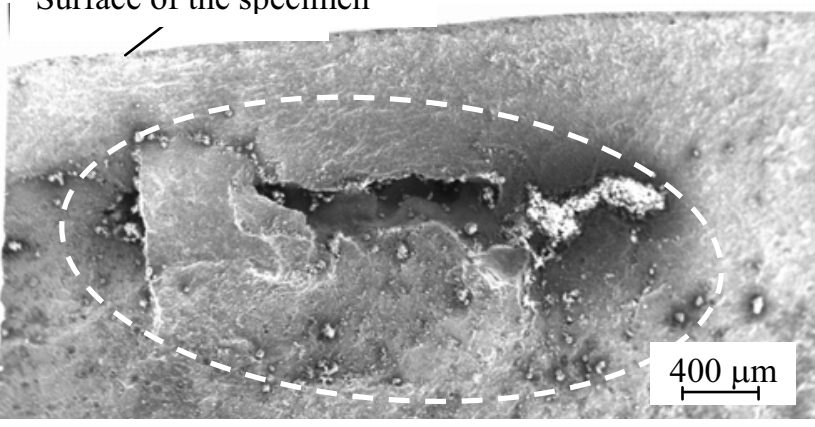

Fig. 10 Defects in the heat affected zone

From analogical cast iron (as cast and normalised) plate CT specimen have been made $(\mathrm{BxHxW}=25 \times 60 \times 50$ $\mathrm{mm})$. By methodology [6], 2 specimens of cast iron and 2 normalized specimens were tested. The dependence between the crack growth rate and stress intensity factor are presented in Fig. 11. We can see that $\Delta K_{\text {th }}$ changes from 7 to $10 \mathrm{MPa} \cdot \mathrm{m}^{1 / 2}$, when the crack growth rate are $v=5 \cdot 10^{-11}$ $10^{-10} \mathrm{~m} /$ cycle, meanwhile of the plate $-\Delta K_{t h} \approx 6.3 \mathrm{MPa} \cdot \mathrm{m}^{1 / 2}$ has been found, when the crack growth rate are $v=1 \cdot 10^{-9}$ $5 \cdot 10^{-10} \mathrm{~m} /$ cycle.

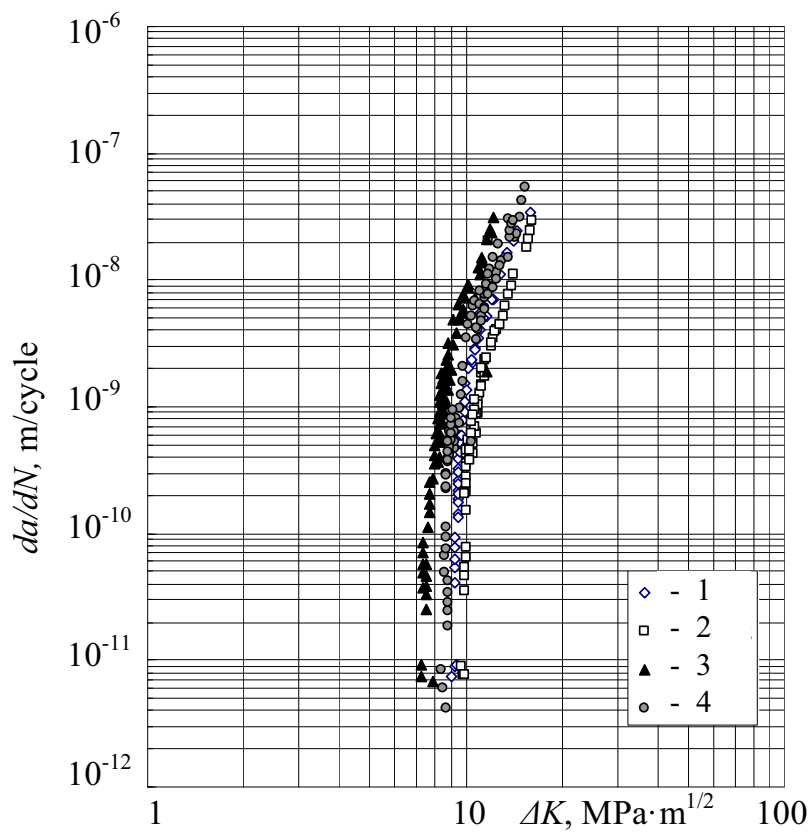

Fig. 11 Crack growth rate versus stress intensity factor range of cast and normalized cast iron (1,2 - normalized; 3, 4 - as cast)

After making the crack growth rates versus stress intensity factor range diagram, additional tests have been performed for establishing compact specimens with a crack static fracture tests, during which were found the indices describing the failure - the critical stress intensity factor $K_{C}$, as well as when all required conditions have been satisfied as well as the fracture toghness $K_{l C}$. This index is defined by the standard ASTM E 399-83. During the experiment of a static failure it is fixed the changeable force $F$ amount and crack opening $v$ and the diagram of their interdependence. For establishing the fracture toughness $K_{I C}$ or the critical stress intensity factor $K_{C}$ it is necessary the value of force $F_{Q}$, found by performing the crack opening diagram analysis. In our investigations the I type of open- 
ing diagram (one of these diagrams is presented in Fig. 12) has been obtained. In this case the force $F_{Q}$ corresponds to 0 -b straight line interaction. This force suits for calculating the fracture toughness $K_{l C}$ value, when it satisfies the condition: $F_{\max } / F_{Q} \leq 1.1$. When this and other conditions of the standard are not satisfied, then only the value describing the critical stress intensity factor $K_{C}$ is calculated. Only a part of the conditions were met from tested specimens 1,2 , 3,4 . These conditions are checked after the test, i.e., was the biaxial strain state at the top of the crack or not, is the plastic deformation on the top of the crack excessive or not, is the crack front line not too curved and whether the ratio $F_{\max } / F_{Q}$ is satisfied. Table presents the $K_{C}$ values of cast and normalised cast iron specimens.

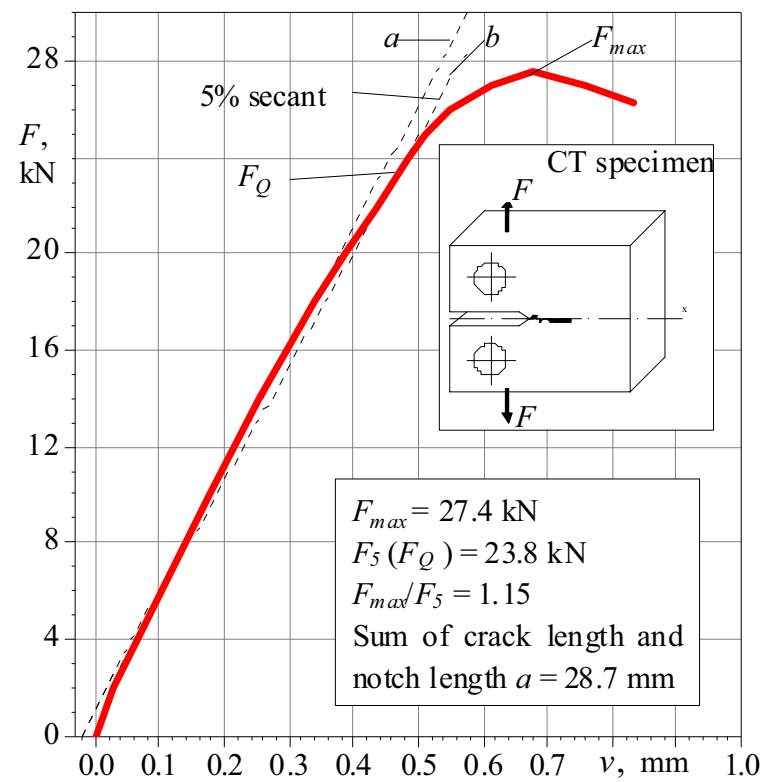

Fig. 12 Notch opening displacement (static fracture diagram) of cast iron compact specimen 3

Critical stress intensity factors of cast

Table and normalized cast iron

\begin{tabular}{|l|c|}
\hline Cast iron specimens & $K_{C}, \mathrm{MPa} \cdot \mathrm{m}^{1 / 2}$ \\
\hline normalized $(1,2)$ & $38.5-47.2$ \\
\hline as cast $(3,4)$ & $52.6-54.6$ \\
\hline
\end{tabular}

The obtained values of limiting stress factors $\Delta K_{t h}$ and $K_{C}$ are applied for designing in mining industry and may be evaluated by the risk according to methods [20].

\section{Conclusions}

1. The experimental investigation has shown that under the stresses close to the operating conditions, no microcracks have been found at $100 \mathrm{mln}$. cycles.

2. Under increasing stresses the crack originates under a surface defect and it reaches surface. The surface roughness and base metal structure influences for further propagation.

3. It was found that a cracking development in surface layers in weld material (in steel) is slower (it include the field of short cracking) and when it pass to the main metal (cast iron), the crack growth rate increases.

4. The obtained kinetic fatigue diagram of welded joint differs from a cast and normalised cast iron crack growth rates versus stress intensity factor range diagram.

5. The obtained threshold stress intensity factor range values of the welded plate $\Delta K_{t h} \approx 6.3 \mathrm{MPa} \cdot \mathrm{m}^{1 / 2}$, when the crack growth rate $v=5 \cdot 10^{-10}-1 \cdot 10^{-9} \mathrm{~m} /$ cycle and CT specimens $\Delta K_{t h}=7-10 \mathrm{MPa} \cdot \mathrm{m}^{1 / 2}$, when the crack growth rate $v=5 \cdot 10^{-11}-10^{-10} \mathrm{~m} /$ cycle.

6 . The critical stress intensity factors of the investigated cast and normalized cast iron $\mathrm{CT}$ specimens vary between large limits: $K_{C}=38.5-54.6 \mathrm{MPa} \cdot \mathrm{m}^{1 / 2}$.

\section{References}

1. Radaj, D.; Sonsino, C.M.; Fricke, W. 2006. Fatigue Assessment of Welded Joints by Local Approaches. Woodhead Publishing Limited and CRC Press LLC. $634 \mathrm{p}$.

2. Schijve, J. 2009. Fatigue of Structures and Materials.Springer Science+Business Media, B.V. 621p.

3. Suresh, S. 2004. Fatigue of Materials. Second editionCambridge university press. $679 \mathrm{p}$.

4. Stonkus, R.; Leonavičius, M. 2010. The high cyclic failure analysis of welded joints of CT specimens, Solid State Phenomena, vol.165 Mechatronic Systems and Materials: Materials Production Technologies. Trans Tech Publications, Switzerland: 183-188.

5. Stonkus, R.; Leonavičius, M.; Krenevičius, A. 2009. Cracking threshold of the welded joints subjected to high-cyclic loading, Mechanika 2(76): 5-10.

6. Leonavičius, M.K.; Krenevičius, A.; Bacevičius, J. 2010. Influence of structure and mechanical properties for cyclic fracture rates of cast iron, Mechanika 2(82): 14-20.

7. Krenevičius, A.; Leonavičius, M.K.; Stonkus, R. 2008. Crack resistence of welds of various types, Eurosteel 2008: 5th European conference on steel and composite structures: research - practice - new materials: 3rd to 5th September 2008 Graz, Austria: proceedings: 911-916.

8. Leonavičius, M.K.; Petraitis, G.; Šukšta, M.; Svalbonas, V. 2006. Strenght of mills and crushers equipment materials subjected to gigacycle loading, Journal of Civil Engineering and Management 12(2): 135-141.

9. Žiliukas, A.; Surantas, A.; Žiogas, G. 2010. Strength and fracture criteria application in stress concentrators areas, Mechanika 3(83): 17-20.

10. Daunys, M.; Stulpinaitè, A.; Šniuolis, R. 2010. Statistical evaluation of low cycle stress-strain curves parameters for alloyed structural steles weld metals at room and elevated temperature, Mechanika 5(85): 5-10.

11. Taylor D.; Hoey D. 2009. High cycle fatigue of welded joints: The TCD experience, International Journal of Fatigue 31: 20-27.

12. Višniakas, I. 2009. Special features of breaking the welded connections of the austenitic $\mathrm{Cr}-\mathrm{Ni}$ austenitic steles. Proc. of 14th International Conference „Mechanika 2009“. Kaunas: Technologija: 434-439.

13. Anderson, T.L. 2005. Fracture Mechanics. Fundamentals and Applications.-Taylor and Francis, Inc. 621p.

14. Sundström, B. 1997. Handbook of Solid Mechanics. -Stockholm: KTH, 1997. 245p. (in Swedish).

15. ASTM E 1681-95.: Standard Test Method for Determining a Threshold Stress Intensity Factor for Envi- 
ronment-Assisted Cracking of Metallic Materials Under Constant Load.

16. Vaičiulis D.; Bražènas A. 2009. Stress concentration coefficient of mechanically heterogeneous welded pipe subjected to internal pressure. Proc. of 14th International Conference „Mechanika 2009“. Kaunas: Technologija: 415-420.

17. Kala, Z. 2008. Fuzzy probability analysis of the fatigue resistance of steel structural members under bending, Journal of Civil Engineering and Management 14(1): 67-72.

18. Vaičiulis, D.; Bražènas, A. 2007. Stress strain state of mechanically heterogeneous welded joint with mild square butt weld subjected to elastic pure bending, Mechanika 1(63): 5-10.

19. Medekshas, H.; Balina, V. 2006. Assessment of low cycle fatigue strength of notched components, Materials \& Design 27(2): 132-140.

20. Zavadskas, E.K.; Turskis, Z.; Tamošaitienė, J. 2010. Risk assessment of construction projects, Journal of Civil Engineering and Management 16(1): 33-46.

R. Stonkus, M. Leonavičius, G. Petraitis, S. Stupak

\section{SUVIRINTOS KETAUS PLOKŠTĖS DAUGIACIKLIO IRIMO ANALIZE்}

\section{R e z i u m è}

Straipsnyje pateikiami pusiau natūrinio suvirinto ketaus bandinio eksperimentiniai analitiniai tyrimo rezultatai. Nustatyta bandinio pagrindinio metalo ir siūlès cheminè sudètis, statinès mechaninès savybès, kietumas ir mikrostruktūra. Bandinio ciklinis apkrovimas eksperimento metu pradetas nuo apkrovimo, artimo realių konstrukcijos elementu apkrovimui. Bandymas atliktas pagal pasirinkta itempių kitimo programą. Remiantis eksperimento duomenimis, sudaryta kinetinè nuovargio diagrama. Irimo sąlygoms nustatyti papildomai atlikta lūžio analizè. Tyrimas papildytas lietų ir normalizuotų CT bandinių eksperimentinių duomenų analize, pasinaudojant plyšio plitimo greičio ir itempių intensyvumo koeficiento priklausomybès diagrama bei plyšio atsivėrimo diagrama. Nustatytos ribinių itempių intensyvumo koeficientų $K_{t h}$ ir $K_{C}$ reikšmès.
R. Stonkus, M. Leonavičius, G. Petraitis, S. Stupak

\section{HIGH-CYCLIC FAILURE ANALYSIS OF WELDED CAST IRON PLATES}

\section{S u m m a r y}

The article presents experimental analytical research results of seminatural welded cast iron specimen. It has been determined: the chemical structure of the base and weld material, static mechanical properties, hardness and microstructure. The static loading during the experiment is started from a close to structural elements loading. The investigation starts from a given stress changing programme. The experiment was performed according to the given programme on stress changing. The kinetic fatigue diagram is performed according to the experimental data. For determining the failure conditions an additional fracture analysis has been performed. The investigation was supplemented by cast and normalised CT samples experimental data analysis by applying the crack growth rate versus stress intensity factor range diagram as well as by the crack opening diagram. Values of limiting stress factors $K_{t h}$ and $K_{C}$ have been determined.

\section{Р. Стонкус, М. Ляонавичюс, Г. Петраитис, С. Ступак}

\section{АНАЛИЗ ЦИКЛИЧЕСКОГО РАЗРУШЕНИЯ СВАРНЫХ СОЕДИНЕНИЙ ИЗ ЧУГУНА}

P е 3 ю м е

В настоящей работе представлены результаты экспериментального аналитического исследования полунатуральных сварных соединений из чугуна. Определены химический состав и механические свойства основного метала и шва. Циклическое нагружение образца проведено по заданной программе, начиная с напряжений, близких к нагрузкам в реальных конструкциях. По экспериментальным данным построена кинетическая диаграмма усталости. Проведен анализ излома позволяющий уточнит условия разрушения. Дополнительно проведено экспериментальное исследование внецентрового растяжения компактных образцов. Построена зависимость между скоростью трещины и коэффициентом интенсивности напряжении. Установлены значения критических коэффициентов интенсивности напряжении $K_{t h}$ и $K_{C}$.

Received December 02, 2010 Accepted April 11, 2011 